\title{
ISSN: 2638-1974

\section{Thermal regime and Hydrocarbon generation in the Apsheron Trough of the South Caspian}

\author{
Yu I. Galushkin ${ }^{*}$
}

Lomonosov Moscow State University, Earth Science Museum, Russian Federation, Russia

\section{Article Info}

\section{*Corresponding author: \\ Galushkin Yu I}

Lomonosov Moscow State University

Earth Science Museum

Russian Federation, Russia

Tel: + 74959391594

E-mail: yu_gal@mail.ru

Received: June 9, 2018

Accepted: June 23, 2018

Published: June 28, 2018

Citation: Yu G. Thermal regime and Hydrocarbon generation in the Apsheron trough of the South Caspian. Int J Petrochem Res. 2018; 2(1): 150-154. doi: 10.18689/ijpr-1000126

Copyright: (c) 2018 The Author(s). This work is licensed under a Creative Commons Attribution 4.0 International License, which permits unrestricted use, distribution, and reproduction in any medium, provided the original work is properly cited.

Published by Madridge Publishers

\begin{abstract}
The earlier modeling helped explain the contradiction between the high thermal regime of the mantle of the South Caspian Basin and the abnormally low temperatures of the upper $6 \mathrm{~km}$ of its sedimentary blanket. The modeling suggested that the "oil window" is located at the depths from 4.5 to $9 \mathrm{~km}$ in the modern sections of the South Apsheron Trough and includes the rocks of the Productive and Pontian formations which are not source rocks in the basin. To solve this problem, we used reconstruction of the thermal history of the basin to restore numerically the history of realization of hydrocarbon potential of the Maikop and Diatomaceous formations. Our modeling shown that the non-steady thermal regime of the mantle in the region and avalanche sedimentation in the Pliocene-Quaternary have shifted the time of intense hydrocarbon generation close to the present time. The maximum generation of light oil by the rocks of the Maikop and Diatomaceous formations occurred for the last 2 to 7 million years when avalanche sedimentation in the Pliocene-Quaternary time took place in the Basin and the powerful layers of weakly compacted highly permeable rocks were created. Assuming the possibility of vertical migration through weakly compacted layers to the horizons with lower temperatures, it can be said that the Upper Maikop and Diatomaceous rocks are promising for the generation of liquid hydrocarbons (mainly of light oil) and gas. The modeling presented in this paper help to understand a leading contribution of the Maikop and Diatomaceous source formations to formation of oil and gas accumulations, despite these suites in present-day sedimentary section locate deeper than the "oil generation window".
\end{abstract}

Keywords: South Caspian, heavy and light oil generation, secondary cracking, vitrinite reflectance

\section{Introduction}

The South Caspian basin is the one of the promising oil and gas regions of the world. The originality of the Basin is huge thickness of the sedimentary cover (over 20 $\mathrm{km}$ ), the extremely high sedimentation rate in the Pliocene (up to $5 \mathrm{~km}$ in million years), and a low degree of compaction of the Pliocene-Quaternary sediments [1] [2] [3]. Thermal regime of the basin is also unusual. It is well known that the South Caspian Basin is characterized by abnormally low temperatures of the rocks in the upper $6 \mathrm{~km}$ of the sedimentary cover [4] [5] [6] [7]. But at the same time, assessments of deep temperatures, as well as the study of the upper mantle by electrical and seismic sounding, show that the studied area is one of the most heated areas of the Caspian region along with the latitudinal belt of the Middle-Caspian [8] [9] [10]. 


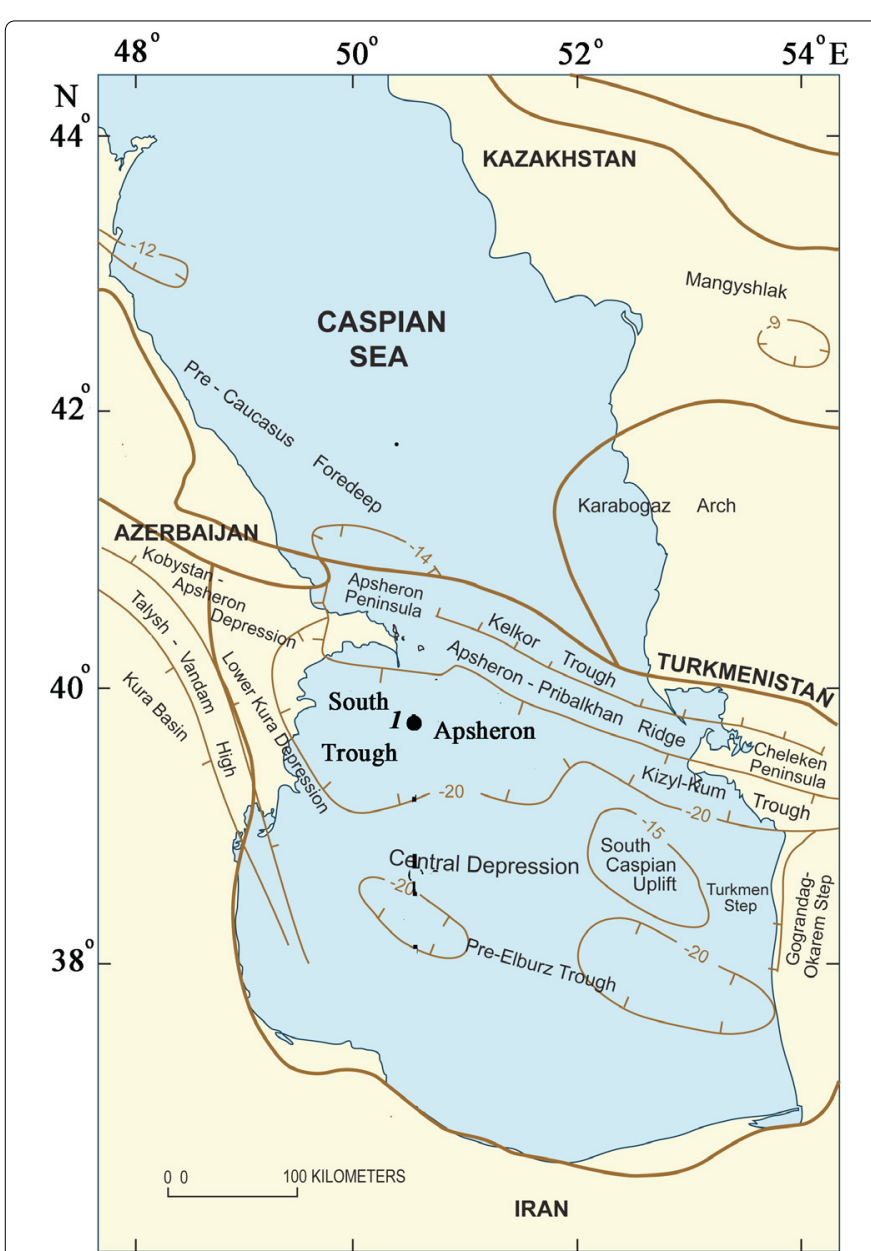

Figure 1. The region under study with approximate location of studied pseudowell 1 in the South Apsheron Trough (according to [8] with changes).

Application of the GALO system for basin modeling [11] [12] allowed us to reconstruct the thermal history of sedimentary blanket of the South Caspian Basin in the South Apsheron Trough (Figure 1) and explain the contradictions between high thermal regime of the mantle and the low rock temperatures in the upper part of the sedimentary cover in the South Caspian Basin [13]. Figure 2 demonstrates the part of general reconstruction of the burial and thermal history of the Basin for last $20 \mathrm{My}$. This reconstruction is in agreement with modern sedimentary section of the basin, established according to drilling data and seismic profiling [2] [14] [15] and with observed values of deep temperatures (Figure 3a) and vitrinite reflectance (Figure 3b). Analysis of the variations in the basin tectonic subsidence in [13] revealed two periods of intensive stretching of the lithosphere with amplitudes: $\beta \approx$ 1.4 and 1.7. These stretchings explain the intense basement subsidence during sedimentation in the Oligocene and Miocene, as well as the avalanche sedimentation in the Pliocene together

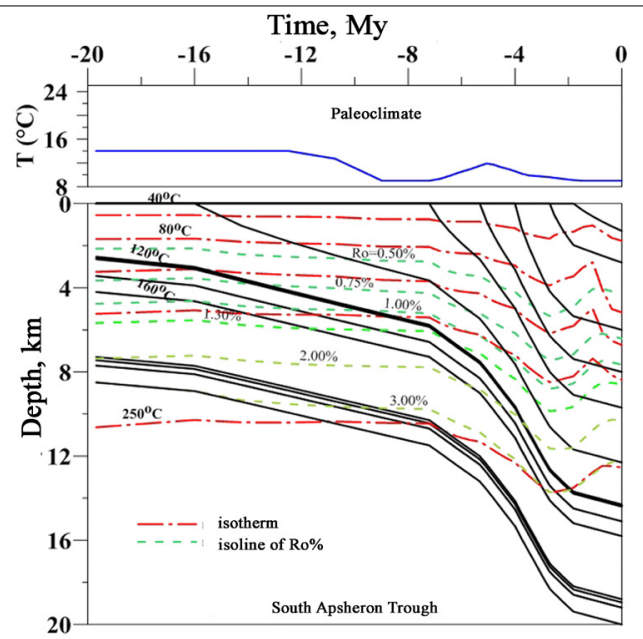

Figure 2. Variation of temperature and catagenesis degree of sedimentary rocks in burial history of the South Caspian Basin in the South Apsheron Trough: detailed history of the last 20 My [13].

with sharp changes in the sea depth in this time [2] [3]. As result of the above stretching periods, the total crust thickness reduced up to $32.4 \mathrm{~km}$ at present time, $20 \mathrm{~km}$ of which are the present-day sedimentary section. Therefore, a thickness of the consolidated crust decreased from initial $35 \mathrm{~km}$ to the present-day value of $12.4 \mathrm{~km}$ [13]. The last value is close to the geophysical estimates of the thickness of the consolidated crust in the Basin [1] [14] [10], and is in accordance with geophysical assessment of thickness of the granitic layer in the South Caspian lithosphere that admit the thickness of this layer no more than 2 - $6 \mathrm{~km}$ [2] [3] [8] [10].

Dotted lines in Figure 2 show the isolines of vitrinite reflectance. In our model, vitrinite reflectance was computed using the EASY-\%Ro model of kinetic spectrum of vitrinite maturation from [16]. The model of thermal evolution of the Basin in figures 2, 3b suggests that the "oil window" $0.50<$ Ro $<1.30 \%$ ) is located at depths from 4.5 to $9 \mathrm{~km}$ in the modern sedimentary sections of the South Apsheron Trough.
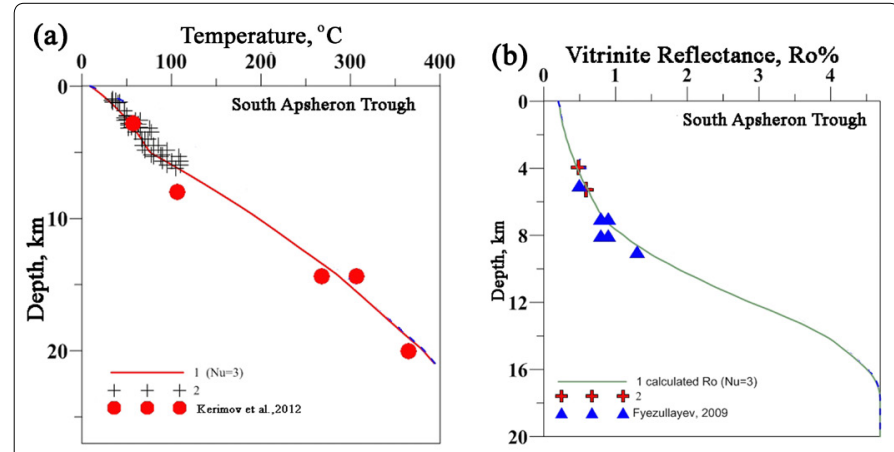

Figure 3. Temperature (left) and vitrinite reflectance (right) distributions with depth in present-day section of the pseudo-well 1 in the South Apsheron Trough [13].

1 - calculated values; 2 (left) - measured deep temperatures in western half of the South Caspian Basin [4] [5] [6]. 2 (right) - Ro-values measured in nearest well of the South Apsheron Trough; 3 - (left) - estimations of deep temperatures according to extrapolation-interpolation equations in [7]. 3 (right) indirect estimations of \%Ro in the area under study by assessment of oil and gas maturity in [17] [18]. 
This depth interval includes the rocks of the Productive and Pontian formations (Figure 4). But these rocks are no source rocks, because they have very low TOC and contain mainly kerogen of the type III. Source rocks in the Basin are the deposits of the Diatomaceous and Maikop formations (Figure 4) that are outside the "oil window" according to the maturity level of organic matter. To explain this contradiction, we use the reconstructions of the thermal history of the sedimentary strata of the basin described in [13] to study a realization of the hydrocarbon potential in the rocks of the Maikop and Diatomaceous source formations.

\section{Hydrocarbon generation by the Maikop and Diatomaceous source rocks}

The Maikop formation of age from 33.9 to 16 My occupies an interval of depths from 12.3 to $14.3 \mathrm{~km}$ in the modern section of the basin. Present-day content of organic matter is $2 \%$.

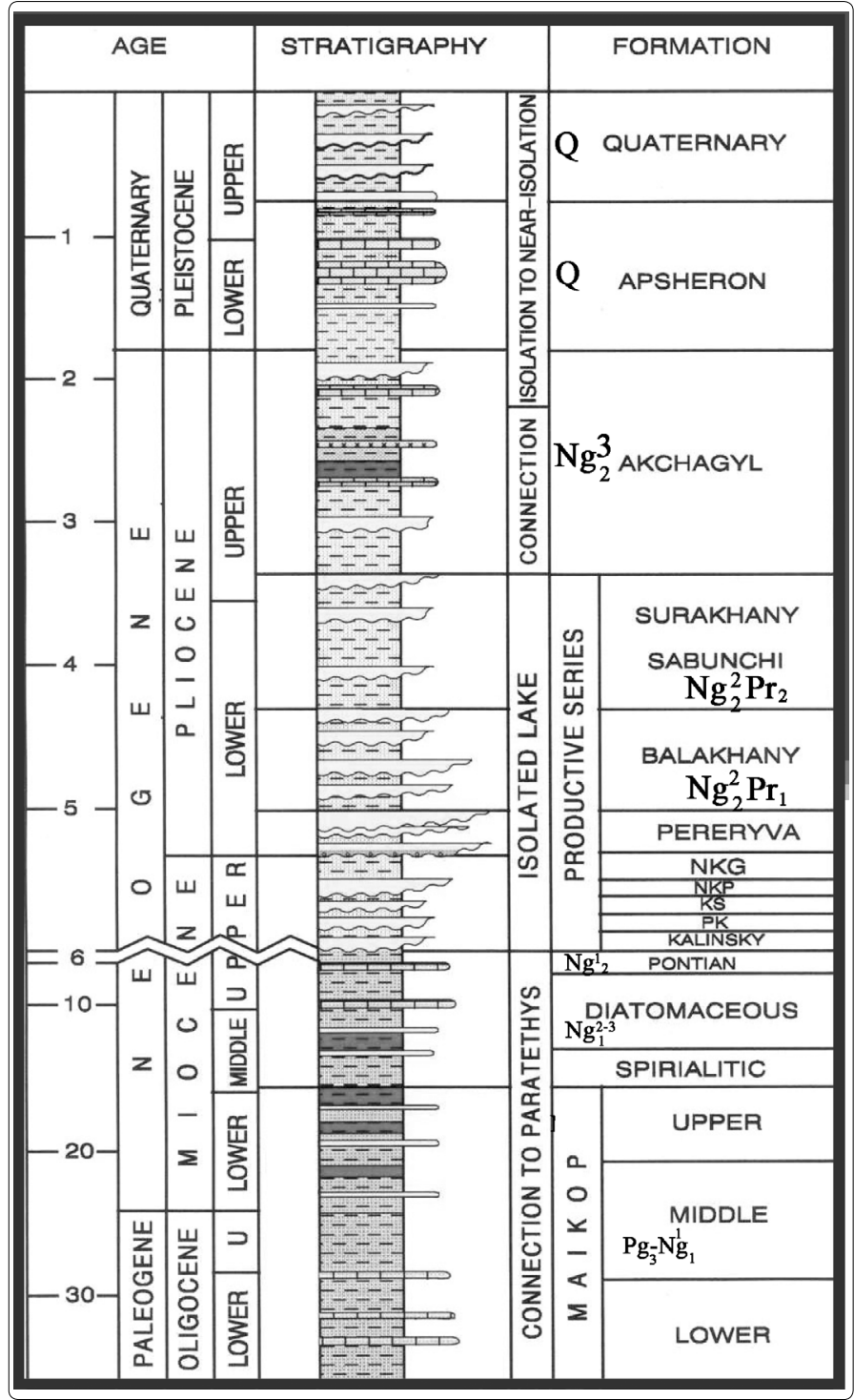

Figure 4. Stratigraphy column of the upper part of sedimentary section of the South Caspian Basin with indication of the Maikop, Diatomaceous and Productive formations [15].

and initial TOC is estimated in the model as $4.7 \%$. According to modeling, the rocks at base of the formation reached temperature of about $280^{\circ} \mathrm{C}$ and maturity level of $3.98 \%$ by vitrinite

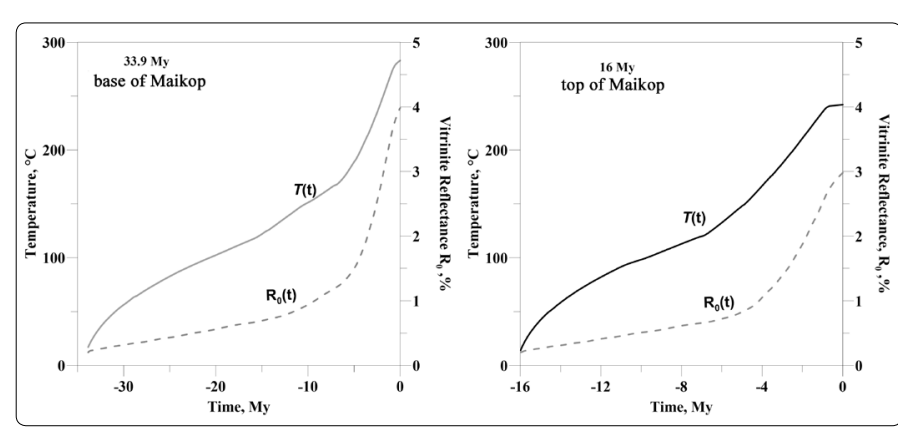

Figure 5. Calculated variations in temperature and vitrinite reflectance during burial history of the rocks at the base and top of the Maikop formation.

reflectance, whereas the rocks at top of the formation reached temperature of about $230^{\circ} \mathrm{C}$ and maturity level of Ro $=2.98 \%$ (Figure 5 ). The temperature and maturity level of the Maikop rocks are rather high and at present time the rocks can be considered as overmature gas prone source rocks. This is confirmed by Figure 6 shown that light and heavy oil have degraded totally to present time due to secondary cracking of kerogene. In these calculations, it was taken into account that kerogen of the Maikop shales is presented by mixture $50 \%$ marine kerogen of type II with initial potential of $\mathrm{HC}$ generation $\mathrm{HI}=611 \mathrm{mg} \mathrm{HC} / \mathrm{g}$ TOC and $50 \%$ kerogen of type III with initial potential of $\mathrm{HC}$ generation $\mathrm{HI}=160 \mathrm{mg} \mathrm{HC} / \mathrm{g}$ TOC, so that the initial potential of hydrocarbon generation of the rock is $\mathrm{HI}=393.5 \mathrm{mg} \mathrm{HC} / \mathrm{g}$ TOC. In calculations, we used the kinetic spectra for cracking of kerogen of types II and III in the 4-fractional model, that was developed in the French Oil Institute (Paris) and are applied in a widespread modeling package MATOIL.

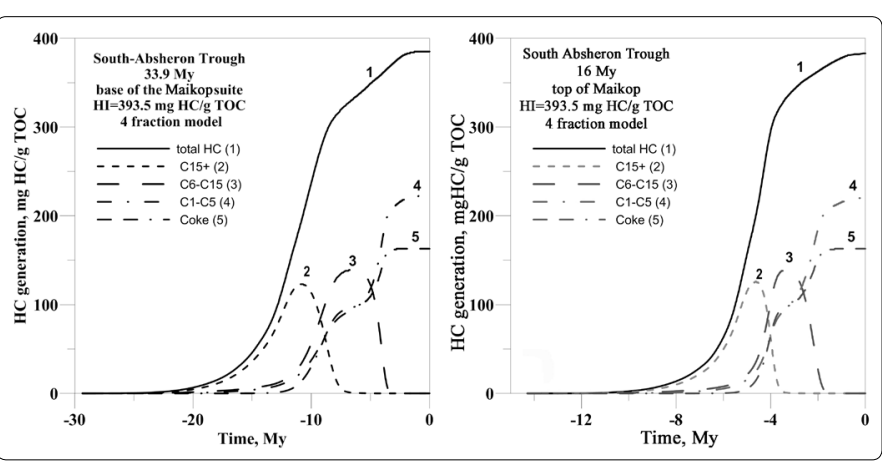

Figure 6. Realization of hydrocarbon potential by the Maikop source rocks in the 4-fractions model of kerogen cracking (heavy and light oil, gas and coke).

Situation with Diatomaceous formation can be seen on Figures 7 and 8. The Diatomaceous formation of age from 16 to $7.2 \mathrm{My}$ occupies an interval of depths from 9.7 to $12.3 \mathrm{~km}$ in the modern section of the basin. Present-day content of organic matter is $1 \%$ and initial TOC is estimated in the model as $2.4 \%$. According to modeling, the rocks at base of the formation reached temperature of about $230^{\circ} \mathrm{C}$ and maturity level of Ro $=2.98 \%$, whereas the rocks at top of the formation reached temperature of about $190^{\circ} \mathrm{C}$ and maturity level of Ro $=1.74 \%$ (Figure 7). The temperature and maturity level of the Diatomaceous rocks are also rather high and at present time the rocks can be considered as high mature and gas prone source rocks. This is partly confirmed by Figure 8 shown that 
light and heavy oil in the rocks at base of formation have degraded totally to present time due to secondary cracking of kerogen (Figure 8). However, in the rocks at top of the Diatomaceous formation the light oil is degraded only partially (Figure 8).

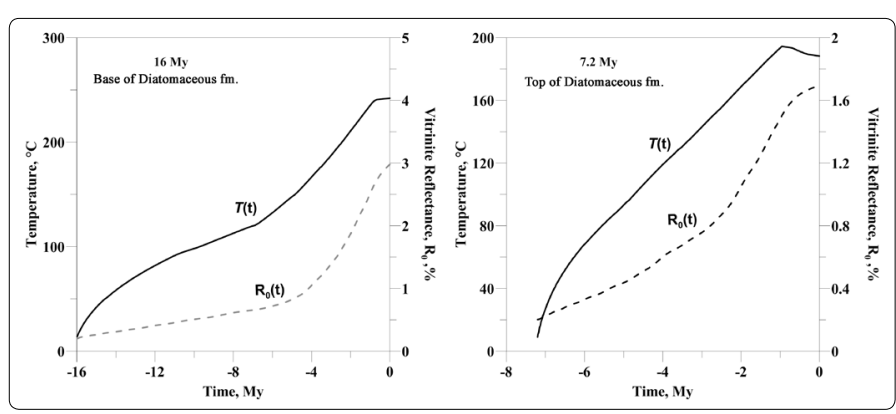

Figure 7. Calculated variations in temperature and vitrinite reflectance during burial history of the rocks at base and top of the Diatomaceous formation.

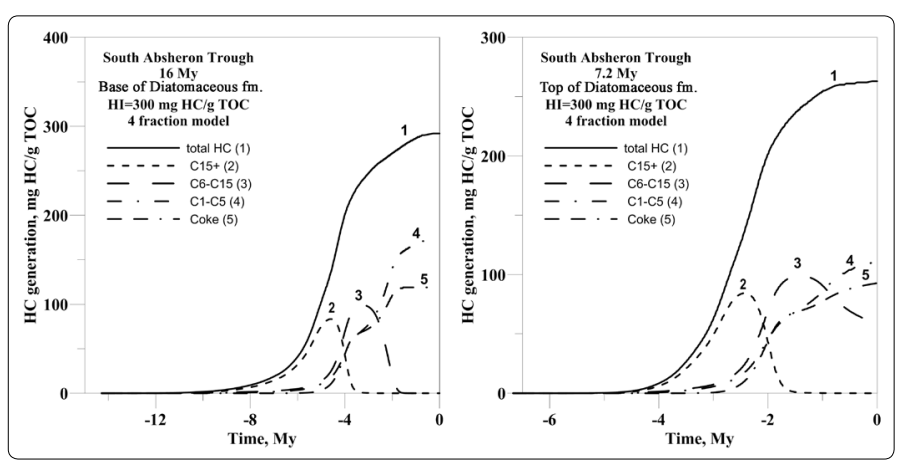

Figure 8 . Realization of hydrocarbon potential by the Diatomaceous source rocks in the 4-fractions model of kerogen cracking (heavy and light oil, gas and coke).

\section{Discussion}

Thus, the simulation suggests that the rocks of the Maikop and Diatomaceous formations in the modern sedimentary section of the South Caspian Basin are mainly gas-generating. However, it is necessary to remember that the geochemical modeling in Figures 6 and 8 assumes that the generated hydrocarbons did not leave the pore space of the source rock. Therefore, only on the basis of present-day situation it cannot be argued that the prospects for the formation of oil fields generated by the rocks of the above formations are small. The fact is that the South Caspian Basin is an unusual sedimentary basin. Here, the unsteady character of thermal regime of the mantle [13] and avalanche sedimentation contributed to the displacement of the processes of maturation of organic matter to the present time. Of course, the rocks of the lower Maikop are mainly gas-generating. But the modeling shows that the secondary cracking of liquid hydrocarbons in the Upper Maikop rocks occurred only 5-10 million years ago and only $2-4$ million years ago in the Diatomaceous rocks (Figures. 6, 8). Liquid hydrocarbons generated by these rocks could quite migrate $3-4 \mathrm{~km}$ vertically through the relatively weakly consolidated rocks of the upper layers and reach the Productive strata with a lower temperature, thereby avoiding P-T conditions of secondary cracking. Then the upper half of the Maikop formation can be considered as promising for the generation of both liquid and gas hydrocarbons. The probability of avoiding hard conditions of secondary cracking for the Diatomaceous rocks was even more because here degradation of heavy and light oils occurred during avalanche sedimentation in the Pliocene-Quaternary time when the powerful layers of weakly compacted highly permeable rocks were created [19]. Assuming the possibility of such vertical migration through weakly compacted layers to the horizons with lower temperatures, it can be said that the Diatomaceous rocks are promising for the generation of liquid hydrocarbons (mainly of light oil) and gas.

\section{Conclusion}

The modeling suggests that the "oil window" is located at depths from 4.5 to $9 \mathrm{~km}$ in the modern sections of the Trough and includes the rocks of the Productive and Pontian formations. But these rocks are no source rocks, because they have very low TOC and contain mainly kerogen of the type III. Source rocks in the Basin are the deposits of the Diatomic and Maikop formations. We explain this contradiction by the fact that the non-steady thermal regime of the mantle in the region and avalanche sedimentation in the PlioceneQuaternary had a significant influence on the history of hydrocarbon generation in the basin, shifting the time of intense hydrocarbon generation to the present time. According to the calculations, the maximum generation of light oil by the rocks of the Maikop and Diatomic formations occurred for the last 2 to 7 million years. Such recent hydrocarbon generation and significant role of vertical migration of hydrocarbons determine leading contribution of the Maikop and Diatomaceous suites to formation of oil and gas accumulations, despite these suites in present-day sedimentary section locate deeper than "oil generation window".

\section{References}

1. Allen BM, Vincent SJ, Izmail-Zadech A, Simmons M, Anderson I. Onset of subduction as the cause of rapid Pliocene-Quaternary subsidence in the South Caspian Basin. Geology. 2002; 30(9): 775-778. doi: 10.1130/0091-7613(2002)030<0775:OOSATC>2.0.CO;2

2. Glumov IF, Malovitsky YP, Novikov AA, Senin BV. Regional geology and hydrocarbon prospect of the Caspian Sea, Moscow, «Nedra-Bisnescentr», 2004 (in Russian).

3. Artyushkov EV. Formation of the super-deep depression in the South Caspian due to phase transitions in the continental crust. Geologiya I Geophizika, 48. 2007; (12): 1289-1306 (in Russian).

4. Bagir-Zadeh FM, Narimanov AA, Babayev FR. Geological and geochemical features of the fields in the Caspian Sea, Nedra, Moscow, 1988 (in Russian).

5. Aliyeva EG. Prediction of deep zones of hydrocarbon's generation and accumulations in central part of the South Caspian Basin. Geologiya Nefti I Gasa, 2003; 5: 20-31 (in Russian).

6. Abasov MT, Aliyarov RY, Kondrushkin YV, Krutysh LG, Mustafayev RT, et al. Thermobaric regime of a section of the South-Caspian sedimentary Basin fields. In: (Ali-Zade, A.A. ed.) "South-Caspian Basin: geology, geophysics, oil, and gas content", Baku, Nafta-Press, 2004; 71-88.

7. Kerimov VY, Rachinsky MZ, Karnauchov SM, Mustaev RN. Geotemperature field of the South Caspian basin. Otechestvennaya Geol. 3, 2012; 17-24 (in Russian). 
8. Smith-Rouch LS. Oligocene-miocene Maykop/Diatom Total Petroleum System of the South Caspian Basin Province, Fzerbaijan, Iran, and Turkmenistan. Bulletin 2201-1. U.S.Geological SurveyReston, Virginia, 2006.

9. Lubimova EA, Feldman IS. Heat flow, temperature, and electrical conductivity of the crust and upper mantle in the U.S.S.R. Tectonophysics v. 1970; 10(1-3): 245-281. doi: 10.1016/0040-1951(70)90110-1

10. Guliev IS, Fedorov DL, Kulakov SI. The Oil-Gas-bearing Caspian Region. Nafta-Press, Baku, 2009 (in Russian).

11. Makhous M, Galushkin Yu I. Basin analysis and Modeling of the Burial, Thermal and Maturation Histories in Sedimentary Basins. Editions TECHNIP, Paris, 2005.

12. Galushkin Yu I. Non-standard Problems in Basin Modeling. Springer International Publishing, Swizeland, 2016.

13. Galushkin Yu I. Numerical reconstructions of thermal evolution of sedimentary cover and underlying lithosphere in western part of the South Caspian Basin. Marine and Petroleum Geology 2017; 88: 1094-1108.
14. Guliev IS, Mamedov PZ, Feyzulayev AA, Huseynov DA, Kadirov FA, Aliyeva EHM, et al. Hydrocarbon Systems of the South Caspian Basin. Nafta-Press, Baku, 2003.

15. Guliev I, Aliyeva E, Huseynov D, Fyezullaeyv A, Mamedov P. Hydrocarbon potential of ultra deep deposits in the South Caspian Basin. In: AAPG European Region Annual Conference. Kiev, Ukraine, October 17-19, 2010.

16. Sweeney JJ, Burnham AK. Evolution of a simple model of vitrinite reflectance based on chemical kinetics. AAPG Bull. 1990; 74(10): 15591570.

17. Feyzullayev AA. Maturity and depth occurrence of the oil and gas sources in South Caspian Basin. Cape Town, South Africa, October 26-29, 2008. In: Search and Discovery Article \#40413, AAPG International Conference and Exhibition, 2009.

18. Feyzullayev A. About retardation of a physicochemical processes in overpressured sediments, South-Caspian basin, Azerbaijan. Nat. Sci. 2011; 3(5): 359-364. doi: 10.4236/ns.2011.35048

19. Buryakovski LA, Chilingar GV, Aminzadeh F. Petroleum geology in the South Caspian Basin. Gulf Professional Publishing, Boston, 2001. 